\title{
Sensitivity of Watermelon Cultigens to Ambient Ozone in North Carolina
}

\author{
Gerald J. Holmes, Department of Plant Pathology, North Carolina State University, Raleigh 27695, and Jonathan \\ R. Schultheis, Department of Horticultural Science, North Carolina State University, Raleigh 27695
}

\begin{abstract}
Holmes, G. J., and Schultheis, J. R. 2003. Sensitivity of watermelon cultigens to ambient ozone in North Carolina. Plant Dis. 87:428-434.

Foliar ozone $\left(\mathrm{O}_{3}\right)$ injury is common on watermelon grown in eastern North Carolina. During the 2000 and 2001 growing seasons, 93 cultivars and breeding lines (i.e., cultigens) were evaluated for foliar injury caused by ambient levels of $\mathrm{O}_{3}$. One tetraploid, 42 diploid, and 50 triploid cultigens were evaluated. Injury developed on all cultigens in both years, but severity of injury varied among cultigens and between years. Visible foliar injury (percent surface area necrotic or chlorotic) was rated 1 week after the first harvest in both years. Mean injury for all cultigens was $39 \%$ in 2000 (range $=16$ to $66 \%$ ) and $20 \%$ in 2001 (range $=2.5$ to 60\%). This corresponded to greater mean seasonal $\mathrm{O}_{3}$ levels (12-h [0900 to $2100 \mathrm{~h} \mathrm{EST}$ ] mean daily $\mathrm{O}_{3}$ concentration between early May and mid-June) in 2000 (58 ppb) than in 2001 (52 ppb). Triploid cultigens were less sensitive to injury than diploid cultigens. Mean injury for all triploids was $31 \%$ in 2000 and $16 \%$ in 2001, whereas injury for diploids was $47 \%$ in 2000 and $25 \%$ in 2001. Injury level was consistently negatively correlated with average number of days between transplanting and harvest. Correlations between injury level and yield, fruit size, fruit shape, and fruit sweetness were inconsistent between years and/or insignificant. $\mathrm{O}_{3}$ tolerance in watermelon cultivars should receive increased attention in watermelon breeding programs and in cultivar selection in areas of high $\mathrm{O}_{3}$ pollution.
\end{abstract}

Additional keywords: abiotic disease, air pollution, Citrullus lanatus, host resistance, seedless

In eastern North Carolina as well as in Europe $(1,4,12)$, visible foliar symptoms caused by ozone $\left(\mathrm{O}_{3}\right)$ are common in watermelon and may be misdiagnosed as nutrient deficiency, drought stress, insect injury, or foliar disease caused by plant pathogens. Consequently, misdiagnosis of $\mathrm{O}_{3}$ injury often leads to misapplication of pesticides that are unlikely to ameliorate the problem. Even when the condition is diagnosed correctly, there is no practical information available on how to ameliorate injury in future years. Although some chemical agents, including the fungicide benomyl $(2,17)$, have been shown to reduce $\mathrm{O}_{3}$-induced injury, their use has generally not been recommended for this purpose. Understanding the relative sensitivity of watermelon cultivars to $\mathrm{O}_{3}$ injury is necessary in order to select watermelon cultivars for planting in areas of high $\mathrm{O}_{3}$ pollution.

In a recent review, Krupa et al. (11) stated that there is a significant need to conduct chamberless field studies to determine the effects of ambient levels of $\mathrm{O}_{3}$

Corresponding author: G. J. Holmes

E-mail: gerald_holmes@ncsu.edu

* The $\boldsymbol{e}$-Xtra logo stands for "electronic extra" and indicates that Figure 1 appears in color in the online edition.

Accepted for publication 11 November 2002.

Publication no. D-2003-0218-02R

(C) 2003 The American Phytopathological Society on plant growth and productivity. In North Carolina, during a watermelon cultigen (i.e., cultivars and breeding lines) comparison trial conducted in 2000 , extensive $\mathrm{O}_{3}$ symptoms (e.g., chlorosis, stippling, interveinal bleaching, necrosis) developed on foliage a few weeks before the first harvest. As observed by other workers $(3,15)$, injury appeared to be cultivar-dependent. Thus, we had an opportunity to evaluate cultivar response under ambient conditions in eastern North Carolina and to evaluate its effects on other cultivar characteristics (e.g., yield and fruit quality). Although there are several published reports characterizing various aspects of $\mathrm{O}_{3}$ injury in watermelon $(4-6,12,15,16)$, none of them have systematically evaluated a large number of cultigens under ambient conditions. Moreover, most of the cultigens tested previously are no longer used commercially. Our objective was to determine $\mathrm{O}_{3}$ sensitivity of a large number of watermelon cultigens, including diploid (seeded) and triploid (seedless) types, and to evaluate the effects of this injury on yield and fruit quality. Brief summaries of this work have been published elsewhere $(9,10)$.

\section{MATERIALS AND METHODS}

Experiments were conducted at the Central Crops Research Station in Clayton, NC. Studies were established on Wagram loamy sand soils (loamy, kaolinitic, thermic arenic kandiudults) in 2000 and Norfolk loamy sand soils (fine-loamy, kaolinitic, thermic typic kandiudults) in 2001.
Nitrogen and potash $\left(\mathrm{K}_{2} \mathrm{O}\right)$ were broadcast and disk incorporated (224 kg 15-0-40 per ha) prior to fumigation. Plots were fumigated with 1,3-dichloropropene and chloropicrin (Telone C-17; Dow Agrosciences, Indianapolis, IN) (93 liters/ha), immediately covered with black plastic $(1.25 \mathrm{~mm})$ (NC Plastic Products, Morganton, NC), and a single drip-irrigation tube (Roberts Irrigation Products, Inc., San Marcos, CA) was placed just beneath the soil surface in the center of each bed. Tubes were $8 \mathrm{~mm}$ thick with $30.5 \mathrm{~cm}$ emitter spacing that provided an average output of 91 liters of water per minute per 30.5 linear meter. A pair of tensiometers (four total) was placed on each side of the field to measure and monitor soil moisture at depths of 15 and $30 \mathrm{~cm}$. Irrigation was scheduled based on an average of the four soil moisture tension readings. When the average value was at or near -15 centibars, plants were irrigated until values were at or near 0 centibar.

Seeds of red-fleshed watermelon cultigens were planted in the greenhouse in a soilless growing medium (Fafard 4P; Conrad Fafard, Inc., Agawam, MA) in $4 \times 4$ cm, LE 1803 transplant trays (Landmark Plastic Corp., Akron, OH) 4 weeks prior to transplanting in the field. Immediately prior to transplanting in the field, plants were drenched in a starter fertilizer solution (238 g 20-20-20 per 100 liters of water) containing an insecticide (45 g diazinon $50 \mathrm{WP}$ per 100 liters of water) for soil insect control. Cultigens were transplanted in an alternating pattern of triploid, diploid within and across rows to allow for sufficient pollination. Experimental units were 6.1-m-long single beds on 3.1-m centers with 2- to 3-m nonplanted alleys at each end. Plants were spaced $0.6 \mathrm{~m}$ apart within the row. All cultigens were replicated four times in a randomized complete block design.

Watermelon was transplanted in early May and rated for $\mathrm{O}_{3}$ injury in mid-July. A total of 93 cultigens were evaluated: 41 diploid (seeded), 51 triploid (seedless), and one tetraploid (female parent used to produce triploid cultivars). We selected this tetraploid because it is a commonly used proprietary parent in several commercial triploid cultivars. It was included to determine its response to $\mathrm{O}_{3}$ and hence its possible role as a source of tolerance in its triploid progeny. For the purpose of a year-toyear comparison, 14 diploid and 17 triploid cultigens were used in both 2000 and 2001.

Plots were maintained for the purpose of collecting cultigen yield and quality data 
(i.e., fruit size, interior and exterior fruit characters). Pest management practices followed recommended guidelines for North Carolina (14). Diagnosis of $\mathrm{O}_{3}$ injury was based on the following criteria: (i) premature necrosis and chlorosis of older foliage with new growth unaffected; (ii) distinctive flecking coalescing into progressively larger bleached interveinal necrosis, bifacial necrosis, and eventually leaf skeletonization; (iii) absence of infectious agents; (iv) uniform distribution within plots on mature leaves; and (v) presence of ozone levels sufficient to cause injury (50 to $120 \mathrm{ppb})(3,13)$. Foliar injury was estimated visually as the percentage of necrotic or chlorotic foliage in individual plots in 5\% increments (0 to $100 \%$ ).

Year 2000. Watermelon was transplanted on 3 May. Sixty-five cultigens were evaluated: 33 diploid and 32 triploid. Fertigation was initiated 1 week after transplanting and applied weekly for 11 weeks. Total fertilizer applied for the entire season was $93 \mathrm{~kg} \mathrm{~N} / \mathrm{ha}$ and $190 \mathrm{~kg} \mathrm{~K} / \mathrm{ha}$. Significant classical symptoms of $\mathrm{O}_{3}$ injury were present on 10 July (date of first harvest). Injury severity was rated on 18 July. Fruit were harvested on 10 and 25 July.

Year 2001. Watermelon was transplanted on 8 May. Sixty cultigens were evaluated: 24 diploid, 35 triploid, and 1 tetraploid. Fertigation was initiated 1 week after transplanting and applied weekly for 14 weeks. Total fertilizer applied for the entire season was $145 \mathrm{~kg}$ N/ha and $293 \mathrm{~kg}$ $\mathrm{K} / \mathrm{ha}$. The difference in the amount of fertilization between 2000 and 2001 was due to a small rate increase and the length of the season in 2001 (i.e., three additional applications). Plots were inspected twice weekly for the presence of $\mathrm{O}_{3}$ injury. Injury severity was rated on 20 July. Fruit were harvested on 10 and 24 July, and 6 and 22 August.

Fruit yield and quality characters. The following characters were determined for each plot: days-to-harvest, individual fruit weight, total fruit weight, fruit shape, and fruit sweetness. Days-to-harvest was calculated as the sum of the number of fruit harvested, multiplied by the number of days between transplanting and harvest (for each fruit), divided by the number of fruit harvested. Individual fruit weight was the sum of all harvested fruit weights divided by the number of fruit harvested. Fruit shape was determined by measuring the length and diameter of five typical fruit from each plot $(1=$ round; $>1=$ oblong to elongate). Sweetness was determined from the centers of five fruit per plot by measuring percent soluble solids using a refractometer (Atago Co., Ltd., Tokyo, Japan).

$\mathrm{O}_{3}$ measurement. Daily 12-h (0900$2100 \mathrm{~h}$ EST) average ambient $\mathrm{O}_{3}$ concentrations (one of the most frequently used exposure indexes [8]) were monitored at the USDA Air Quality Research Unit in Raleigh (17 km from the test site) with a UV analyzer (TECO Model 49, Thermo Environmental Instruments, Inc., Franklin, MA) calibrated biweekly with a TECO Model 49 PS calibrator.

Statistical analyses. Foliar injury data were square-root transformed to stabilize the variance over the range of estimated injury. Differences in mean percent foliar injury for each cultigen within years were tested by analysis of variance (ANOVA) using the SAS General Linear Model Procedure (Statistical Analysis Systems version 8.2; SAS Institute Inc., Cary, NC). Mean separation was performed $(P=0.05)$ by Fisher's (protected) LSD. For the 32 cultivars common to both years, the SAS MIXED procedure was used to test for effects by cultivar, year, block, and ploidy. Differences between years in the injury level of individual cultigens was evaluated by calculating the difference of each cultigen's injury rating from the mean injury rating in 2000 and comparing it to the same value for 2001. Simple linear correlations were calculated for injury versus mean days-to-harvest, total harvested fruit weight, mean individual fruit weight, sweetness (percent soluble solids), and fruit shape (length/diameter) for both years using the SAS CORR procedure. Expected values for a normal distribution of cultigen sensitivity were calculated from the observed frequency distribution using the SAS UNIVARIATE procedure.

\section{RESULTS}

Visible $\mathrm{O}_{3}$ injury developed on the foliage of all cultigens tested in both years. Symptoms began as a general chlorosis of the older leaves approximately 25 days prior to the first harvest. In this study, the first distinctive symptom of $\mathrm{O}_{3}$ injury was small necrotic flecks or stippling on the adaxial leaf surface. Small flecks coalesced into progressively larger, bifacial necrotic areas. Necrosis was usually white or "bleached" at first, darkening with time. Necrotic areas enlarged progressively until they cracked and flaked off, leaving only the main leaf veins intact (Fig. 1A to F)
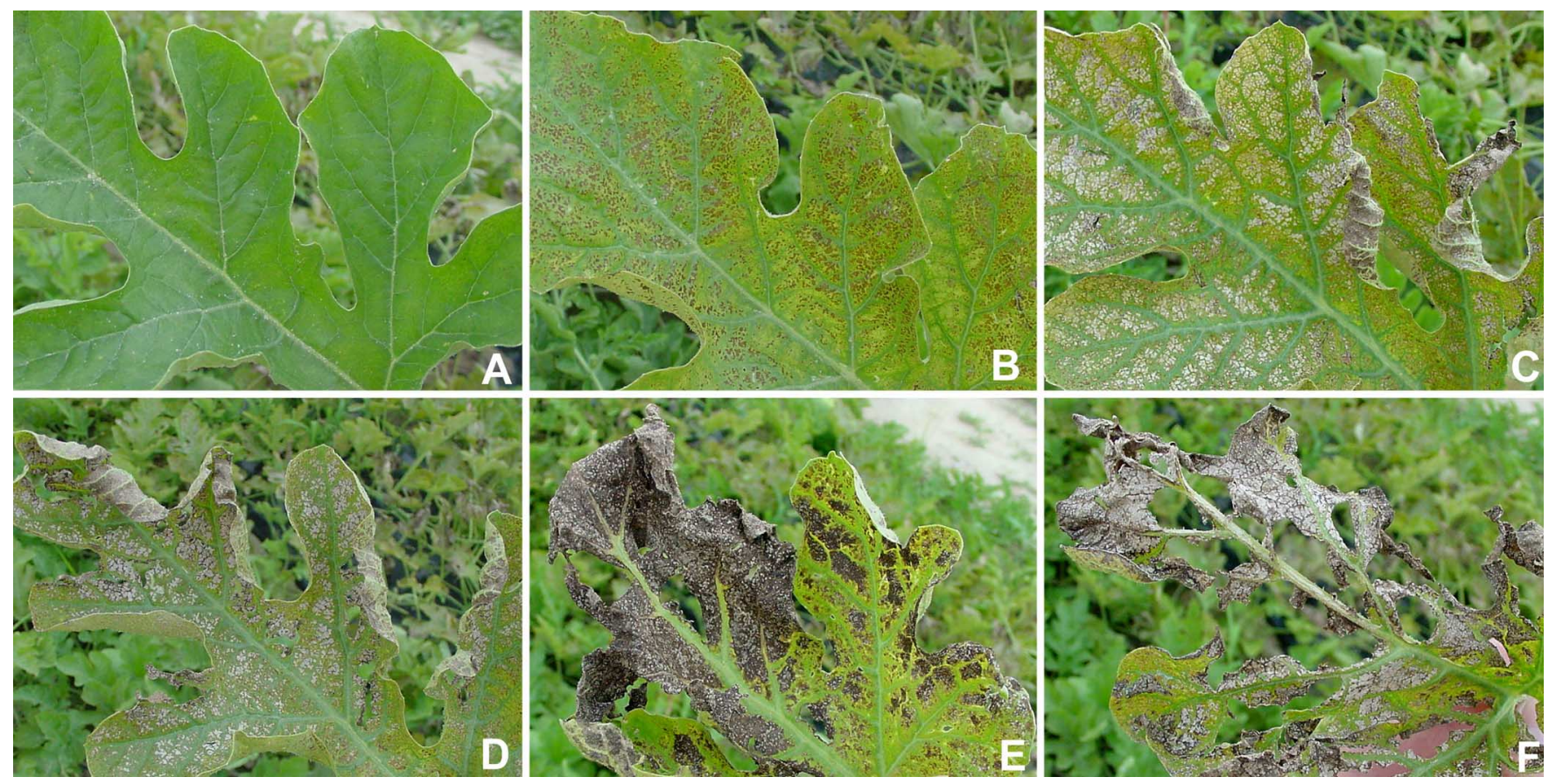

Fig. 1. Progressive levels of $\mathrm{O}_{3}$ injury on watermelon foliage. All leaves were collected from the same plot on the same day. A, Healthy leaf. B, Chlorosis and mild necrotic flecking. C, Bleached necrosis and curling of leaf margins. D, Bleached necrosis enlarging and darkening. E, Coalesced necrotic areas beginning to flake off. F, Necrotic tissue extensively flaked off leaving only main veins intact. 
Injury first appeared on crown leaves; new growth (i.e., leaves not fully expanded) was unaffected. The rate of symptom development (i.e., time between appearance of initial symptoms and severe symptoms) was 3 to 5 weeks depending on the year and the cultigen. In 2001, $\mathrm{O}_{3}$ injury was first detected in a few plots on 26 June and peaked (all plots) approximately 10 days after the first harvest (20 July). The point of first detection was not determined in 2000 , but injury peaked about the same time relative to the first harvest.

Cultigens differed significantly in their sensitivity to $\mathrm{O}_{3}$ injury (Table 1 ). In 2000, the range of foliar injury found in individual plots was 5 to $85 \%$ with a mean of 39\%. Cultigens 'W 5051,' 'W 5052,' 'Millionaire,' and 'HMX 8913' were the most tolerant with $20 \%$ or less foliar injury. The most sensitive cultigens were 'SXW 5023,' 'Stars N Stripes,' 'SF var. 800,' and 'Pinata LS' with $59 \%$ or more foliar injury. In 2001 , the range of foliar injury was 1 to $70 \%$ with a mean of $20 \%$ (Table 1). Cultigens 'Virtigo,' 'RWT 8120,' and 'Trillion' were the most tolerant with $8 \%$ or less foliar injury. The most sensitive cultigens were 'Sugar Baby,' 'W 5023,' and 'Montreal' with $44 \%$ or more foliar injury. Mean injury for cultigens that were common to both years was greater in $2000(37 \%)$ than in 2001 (21\%) (Table 1). This corresponded to greater seasonal $\mathrm{O}_{3}$ levels in 2000 (58 ppb) than in 2001 (52 ppb) (Fig. 2). These ambient $\mathrm{O}_{3}$ levels are common for this area and time of year and are approximately twice as high as estimated normal background levels for areas without anthropogenic inputs $(7,18)$. ANOVA on foliar injury of cultigens used in both years detected significant year, ploidy, year by ploidy, cultivar within ploidy, and year by cultivar within ploidy effects.

While there was a significant difference in the level of ozone injury between years, most cultigens maintained a similar ranking relative to mean injury (Table 2). Of the 32 cultigens evaluated in both years, 14 varied less than $5 \%$ from the mean between 2000 and 2001. An additional 13 cultigens varied between 6 and 15\%. However, 5 cultigens ('SF var. 800,' 'Starbrite,' 'Pinata LS,' 'WX 8,' and 'Premiere') varied between 16 and $27 \%$. For example, 'SF var. 800' sustained the highest level of injury $(60 \%)$ in $2000(21 \%$ above the mean), while in 2001 (at $17 \%$ injury) it was $4.5 \%$ below the mean (Table 2 ).

Triploid watermelon cultigens manifested significantly less $\mathrm{O}_{3}$ injury than diploid cultigens in both years (Fig. 3A and B). This was true for all cultigens as well as cultigens that were used in both years (i.e., common cultigens). Mean injury for all triploid cultigens was $31 \%$ in 2000 and $16 \%$ in 2001 , whereas mean injury for all diploid cultigens was $47 \%$ in 2000 and $25 \%$ in 2001 . In 2000, the 22 least sensitive cultigens were triploid (Table 1). The
Table 1. Foliar injury of watermelon cultigens induced by ambient $\mathrm{O}_{3}$ in 2000 and 2001 at Clayton, $\mathrm{NC}$

\begin{tabular}{|c|c|c|c|c|c|c|}
\hline \multirow{3}{*}{$\frac{\text { Cultigen }}{\text { Not disclosed }}$} & \multicolumn{4}{|c|}{ Visible foliar injury $^{\mathrm{w}}(\%)$} & \multirow[b]{2}{*}{ Ploidy } & \multirow[b]{2}{*}{ Cultigen source ${ }^{x}$} \\
\hline & \multicolumn{2}{|c|}{2000} & \multicolumn{2}{|c|}{2001} & & \\
\hline & - & & 23 & $d-m$ & Tetraploid & Syngenta \\
\hline ACX 257 & 26 & $\mathrm{q}-\mathrm{x}^{\mathrm{y}}$ & - & & Triploid & Abbott \& Cobb \\
\hline ACX 5411 & 54 & a-g & _- & & Diploid & Abbott \& Cobb \\
\hline ACX 5451 & 51 & $a-i$ & - & & Diploid & Abbott \& Cobb \\
\hline ACX 8238 & - & & 11 & $\mathrm{q}-\mathrm{u}$ & Triploid & Abbott \& Cobb \\
\hline Afternoon Delight & - & & 16 & $\mathrm{k}-\mathrm{s}$ & Triploid & D. Palmer Seed \\
\hline Athens $^{\mathrm{z}}$ & 58 & $a-d$ & 29 & $c-g$ & Diploid & Sunseeds \\
\hline Celebration & 38 & $f-r$ & 18 & $h-r$ & Diploid & Syngenta \\
\hline Charleston Gray & - & & 14 & m-t & Diploid & Wyatt-Quarles Seed \\
\hline Cooperstown & _- & & 17 & $1-t$ & Triploid & Seminis \\
\hline Corporal & 35 & $\mathrm{i}-\mathrm{u}$ & - & & Diploid & Seminis \\
\hline Crimson Sweet & 41 & $d-p$ & 28 & $c-i$ & Diploid & Willhite Seed \\
\hline Delta & 49 & $a-j$ & - & & Diploid & Seminis \\
\hline Disko & - & & 11 & $\mathrm{q}-\mathrm{u}$ & Triploid & Hazera Genetics \\
\hline Dumara & 40 & $d-p$ & 26 & $c-j$ & Diploid & Sunseeds \\
\hline Elation & 29 & $\mathrm{~m}-\mathrm{w}$ & - & & Triploid & D. Palmer Seed \\
\hline Enchantment & 38 & $f-s$ & - & & Triploid & D. Palmer Seed \\
\hline EX 4510759 & 35 & $h-t$ & 11 & $q-u$ & Triploid & Seminis \\
\hline EX 4590339 & 21 & $\mathrm{u}-\mathrm{x}$ & - & & Triploid & Seminis \\
\hline Falcon & 46 & $b-l$ & 21 & $e-o$ & Diploid & Seminis \\
\hline Fantastik & - & & 11 & $\mathrm{q}-\mathrm{u}$ & Triploid & Abbott \& Cobb \\
\hline Festival & 46 & $a-k$ & 29 & $c-h$ & Diploid & Willhite Seed \\
\hline Fiesta & 41 & $c-p$ & 23 & $e-p$ & Diploid & Syngenta \\
\hline Freedom & 21 & $t-x$ & 15 & $l-s$ & Triploid & Sunseeds \\
\hline Gem-Dandy & 35 & $i-u$ & 31 & $b-e$ & Triploid & Willhite Seed \\
\hline Hazera 103 & - & & 9 & stu & Triploid & Hazera Genetics \\
\hline HMX 8913 & 20 & vwx & - & & Triploid & Harris Moran \\
\hline HMX 8914 & 22 & $s-x$ & 14 & $n-u$ & Triploid & Harris Moran \\
\hline Jubilee & -- & & 18 & $\mathrm{k}-\mathrm{s}$ & Diploid & Wyatt-Quarles Seed \\
\hline Lady & 46 & b-1 & - & & Diploid & Sunseeds \\
\hline Mara & - & & 23 & $d-m$ & Diploid & Siegers Seed \\
\hline Mardi Gras & 35 & $i-u$ & 15 & $l-s$ & Diploid & Syngenta \\
\hline Margarita & - & & 31 & $b-f$ & Diploid & Southwestern Seed \\
\hline Millenium & 25 & $r-x$ & 20 & $g-q$ & Triploid & Harris Moran \\
\hline Millionaire & 20 & $v w x$ & 13 & $p-u$ & Triploid & Harris Moran \\
\hline Montreal & - & & 44 & $\mathrm{ab}$ & Diploid & Sunseeds \\
\hline Pinata $L S$ & 59 & $a-e$ & 23 & $e-p$ & Diploid & Willhite Seed \\
\hline Pinata SS & 45 & b-n & - & & Diploid & Willhite Seed \\
\hline Premiere & 28 & $p-x$ & 28 & $c-h$ & Triploid & Southwestern Seed \\
\hline Regency & 54 & $a-h$ & 24 & $c-l$ & Diploid & Seminis \\
\hline Revolution & 24 & $r-x$ & 13 & $n-u$ & Triploid & Sunseeds \\
\hline RWM 8036 & 42 & b-p & - & & Diploid & Syngenta \\
\hline RWM 8073-VP & 38 & $\mathrm{f}-\mathrm{r}$ & - & & Triploid & Syngenta \\
\hline RWM 8089-VP & 41 & b-p & - & & Triploid & Syngenta \\
\hline RWM 8114 & - & & 23 & $\mathrm{c}-\mathrm{m}$ & Diploid & Syngenta \\
\hline RWT 8096-VP & - & & 18 & h-r & Triploid & Syngenta \\
\hline RWT 8120 & - & & 7 & uv & Triploid & Syngenta \\
\hline SeedWay 4502 & 30 & $l-w$ & 19 & $g-r$ & Triploid & SeedWay \\
\hline Sentinel & 48 & $a-j$ & 29 & $c-g$ & Diploid & Seminis \\
\hline SF var. 5544 & 35 & $\mathrm{i}-\mathrm{u}$ & - & & Triploid & Abbott \& Cobb \\
\hline SF var. 800 & 60 & $a b$ & 17 & $k-s$ & Diploid & Abbott \& Cobb \\
\hline SF var. 900 & 36 & h-t & - & & Diploid & Abbott \& Cobb \\
\hline SF var. 910 & 51 & $a-i$ & - & & Diploid & Abbott \& Cobb \\
\hline Slice N' Serve 830 & 29 & $n-x$ & 16 & $j-r$ & Triploid & Southwestern Seed \\
\hline SS HQ Var 7167 & - & & 15 & $1-\mathrm{t}$ & Triploid & Abbott \& Cobb \\
\hline SS HQ Var 7177 & - & & 14 & $\mathrm{o}-\mathrm{u}$ & Triploid & Abbott \& Cobb \\
\hline SS HQ Var 7187 & _- & & 18 & h-r & Triploid & Abbott \& Cobb \\
\hline SS var. 5244 & 29 & $\mathrm{~m}-\mathrm{x}$ & - & & Triploid & Abbott \& Cobb \\
\hline Starbrite & 51 & $a-i$ & 13 & $o-u$ & Diploid & Seminis \\
\hline Stargazer & 36 & $g-S$ & 34 & $b-c$ & Diploid & Seminis \\
\hline
\end{tabular}

(continued on next page)

${ }^{\mathrm{w}}$ Injury severity scale based on percent chlorotic and necrotic foliage resulting from exposure to $\mathrm{O}_{3}$ (0 to $100 \%)$.

x Abbott and Cobb, Feasterville, PA; D. Palmer Seed, Yuma, AZ; Harris Moran, Modesto, CA; Hazera Genetics, El Segundo, CA; Sakata Seed, Morgan Hill, CA; SeedWay, Elizabethtown, PA; Seminis, Oxnard, CA; Siegers Seed, Holland, MI; Southwestern Seed, Casa Grande, AZ; Sunseeds, Morganhill, CA; Syngenta, Boise, ID; Willhite Seed, Poolville, TX; Wyatt-Quarles Seed, Garner, NC.

${ }^{\mathrm{y}}$ Values are means of four replicates; treatments followed by the same letter are not significantly different according to Fisher's protected LSD, $P=0.05$; although values presented are percentages, analysis of variance and mean separation were performed on square-root-transformed data.

${ }^{\mathrm{z}}$ Italics indicate cultigens used in both years. 
Table 1. (continued from previous page)

\begin{tabular}{|c|c|c|c|c|c|c|}
\hline \multirow{3}{*}{$\frac{\text { Cultigen }}{\text { Stars N Stripes }}$} & \multicolumn{4}{|c|}{ Visible foliar injury $^{w}(\%)$} & \multirow{3}{*}{$\begin{array}{l}\text { Ploidy } \\
\text { Diploid }\end{array}$} & \multirow{3}{*}{$\begin{array}{l}\text { Cultigen source }^{\mathrm{x}} \\
\text { Seminis }\end{array}$} \\
\hline & \multicolumn{2}{|c|}{2000} & \multicolumn{2}{|c|}{2001} & & \\
\hline & 60 & $a b c$ & - & & & \\
\hline Sugar Baby & - & & 50 & $\mathrm{a}$ & Diploid & Wyatt-Quarles Seed \\
\hline Sunday Special & - & & 21 & e-p & Triploid & Hazera Genetics \\
\hline SWD 8307 & 49 & $a-j$ & - & & Diploid & Sakata Seed America \\
\hline Sweet Eat'N & - & & 18 & i-r & Triploid & D. Palmer Seed \\
\hline Sweetheart & - & & 18 & h-r & Triploid & Seigers Seed Co. \\
\hline SWT 6703 & 32 & $j-v$ & - & & Triploid & Sakata Seed America \\
\hline SWT 8705 & 38 & $\mathrm{f}-\mathrm{s}$ & - & & Triploid & Sakata Seed America \\
\hline SWT 8706 & 35 & $\mathrm{i}-\mathrm{u}$ & - & & Triploid & Sakata Seed America \\
\hline SWT 8707 & 30 & $\mathrm{k}-\mathrm{w}$ & - & & Triploid & Sakata Seed America \\
\hline SWT 9708 & 40 & $\mathrm{~d}-\mathrm{q}$ & - & & Triploid & Sakata Seed America \\
\hline SWX-190 & - & & 11 & $\mathrm{q}-\mathrm{u}$ & Diploid & Southwestern Seed \\
\hline SXW 5023 & 66 & a & - & & Diploid & Sunseeds \\
\hline SXW 5036 & 39 & e-r & - & & Diploid & Sunseeds \\
\hline Til & 45 & $b-m$ & 34 & $b c d$ & Triploid & D. Palmer Seed \\
\hline Trillion & - & & 8 & tu & Triploid & Abbott \& Cobb \\
\hline Triple Crown & - & & 25 & $\mathrm{c}-\mathrm{k}$ & Triploid & SeedWay \\
\hline Triple Prize & 41 & b-p & - & & Triploid & SeedWay \\
\hline $\operatorname{Tr} i-X-313$ & 28 & $o-x$ & 20 & $f-p$ & Triploid & Syngenta \\
\hline Tri-X-Palomar & 44 & $b-o$ & 24 & $d-n$ & Triploid & Syngenta \\
\hline Tri-X-Shadow & 35 & $\mathrm{i}-\mathrm{u}$ & - & & Triploid & Syngenta \\
\hline Virtigo & - & & 3 & $\mathrm{v}$ & Triploid & Hazera Genetics \\
\hline W 5023 & - & & 44 & $a b$ & Diploid & Sunseeds \\
\hline W 5051 & 16 & $x$ & 12 & $r-u$ & Triploid & Sunseeds \\
\hline$W 5052$ & 19 & $w x$ & 13 & $p-u$ & Triploid & Sunseeds \\
\hline W 8062 & - & & 29 & $\mathrm{c}-\mathrm{g}$ & Triploid & Sunseeds \\
\hline Wrigley & 32 & $j-v$ & 11 & $q-u$ & Triploid & Seminis \\
\hline WX 22 & 55 & $a-f$ & - & & Diploid & Willhite Seed \\
\hline WX 24 & 38 & $\mathrm{f}-\mathrm{s}$ & - & & Diploid & Southwestern Seed \\
\hline WX 30 & 45 & b-m & - & & Diploid & Southwestern Seed \\
\hline$W X 55$ & 38 & $f-r$ & 18 & $j-r$ & Triploid & Willhite Seed \\
\hline$W X 8$ & 41 & $d-q$ & 21 & $f-p$ & Diploid & Southwestern Seed \\
\hline XP 4525247 & 42 & $\mathrm{~b}-\mathrm{p}$ & - & & Diploid & Seminis \\
\hline Number of entries & 65 & & 60 & & 93 & \\
\hline Mean (common cvs.) & 37 & & 21 & & & \\
\hline Mean (all cvs.) & 39 & & 20 & & & \\
\hline Mean (all diploids) & 47 & & 25 & & & \\
\hline Mean (all triploids) & 31 & & 16 & & & \\
\hline
\end{tabular}

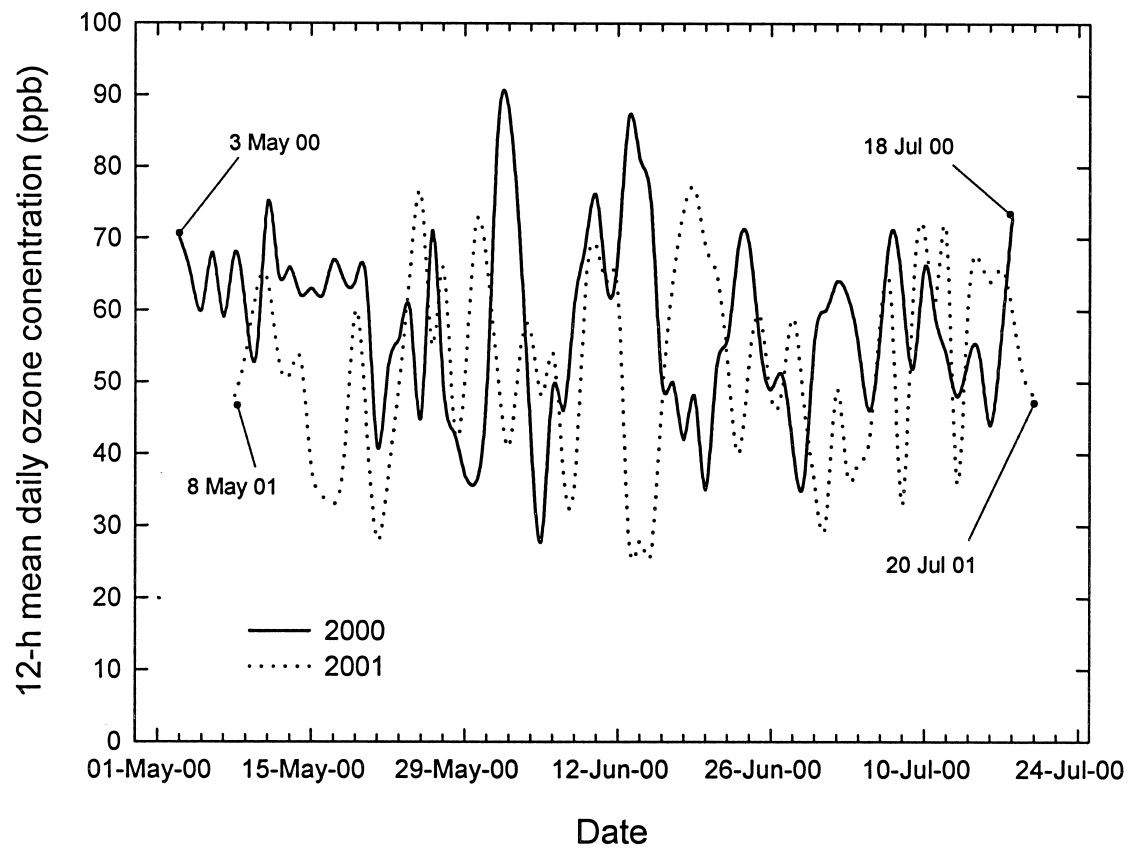

Fig. 2. Daily (12-h [0900 to $2100 \mathrm{~h}$ EST] mean) ambient air $\mathrm{O}_{3}$ concentrations recorded in Raleigh, $\mathrm{NC}$, between transplanting and final evaluation of ozone injury. The seasonal mean 12-h/day concentration for 3 May to 18 July 2000 was 58 ppb and for 8 May to 20 July 2001 was 52 ppb. tetraploid had a mean injury rating of $23 \%$, slightly above the mean injury rating for all cultigens in 2001 (Table 1).

Fruit yield and quality characters. All correlations between injury levels and yield and fruit quality characters were relatively low $(r \leq 0.48)$. The highest and most consistent correlation was a negative relationship between injury and days-toharvest (i.e., greater injury was correlated with fewer days to harvest) in both years (Table 3). Injury levels were consistently negatively correlated with total harvested weight, but this was only significant in 2001. Fruit weight was significantly and positively correlated with injury in 2000 , but nonsignificantly and negatively correlated in 2001. Fruit shape (length/diameter) was negatively correlated with injury in both years among all cultigens, but was only significant in 2000. However, a positive correlation with fruit shape in both years existed for common cultigens, but was only significant in 2000. Correlations between injury levels and soluble solids were consistently negative and significant in 2000 .

\section{DISCUSSION}

In this study, 93 watermelon cultigens were characterized for $\mathrm{O}_{3}$ injury under ambient conditions in eastern North Carolina. All tested cultigens developed visible foliar injury caused by ambient levels of O3, but sensitivity varied among cultigens and between years. Cultigens with high tolerance to $\mathrm{O} 3$ exist and include widely grown commercial cultivars such as 'Millionaire' and 'Revolution' and the newly released 'Virtigo.' These cultivars offer an effective means of reducing injury while maintaining desirable horticultural characters. Popular diploid cultivars that are highly sensitive to O3 injury include 'SF var. 800,' 'Regency,' 'Starbrite,' and 'Sentinel.'

Most cultigens ranked similarly to one another from one year to the next despite differences in cultural practices (e.g., fertilization), soil type, weather, and ambient $\mathrm{O}_{3}$ levels. Decoteau et al. (3) reported a similar result when they tested 13 cultigens (2 sites, 1 year) and speculated that the variability in a single cultivar between sites might be due to management practices or other environmental stresses. In our study, it appears that the tolerance of some cultigens to O3-induced foliar injury is overcome under higher $\mathrm{O} 3$ levels, whereas under lower O3 levels tolerance is maintained (e.g., 'SF var. 800'). Regardless of the mechanism responsible, it is important to note that while most cultigens respond similarly to ozone, there are notable exceptions.

Cultivars 'Sugar Baby,' 'Charleston Gray,' and 'Crimson Sweet' have existed for many years and were tested for their sensitivity to $\mathrm{O}_{3}$-induced injury by earlier workers $(3,15,16)$. The level of injury reported for these cultivars in these studies was similar to that reported here. For example, 'Sugar Baby' was the most suscep- 
tible cultivar evaluated by Decoteau et al. (3), who reported 62.5 and $47.5 \%$ injury at two sites within the same year. Likewise, 'Sugar Baby' was the most sensitive cultivar we evaluated in 2001 with $50 \%$ injury. 'Crimson Sweet' was one of the most sensitive cultivars we tested with $20 \%$ injury in 2000 and $25 \%$ injury in 2001 . In contrast, Decoteau et al. (3) reported 11 and
$24 \%$ injury for 'Crimson Sweet,' and Simini et al. (15) reported 55, 37, and 58\% injury in 1985, 1986, and 1987, respectively, on this cultivar. 'Charleston Gray' is considered somewhat tolerant to ozone. In our study, this cultivar had $14 \%$ foliar injury in 2001. However, both Decoteau et al. (3) and Simini et al. (15) obtained variable results with this cultivar (as low as

Table 2. Comparison of foliar injury in 2000 and 2001 relative to the mean of each year

\begin{tabular}{|c|c|c|c|c|c|}
\hline \multirow[b]{2}{*}{ Cultigen } & \multicolumn{2}{|c|}{2000} & \multirow[b]{2}{*}{ Difference $^{\mathrm{z}}$} & \multicolumn{2}{|c|}{2001} \\
\hline & $\begin{array}{c}\text { Foliar injury } \\
(\%)\end{array}$ & $\begin{array}{c}\text { Deviation } \\
\text { from mean }\end{array}$ & & $\begin{array}{l}\text { Deviation } \\
\text { from mean }\end{array}$ & $\begin{array}{c}\text { Foliar injury } \\
(\%)\end{array}$ \\
\hline Festival & 46 & 8.5 & 1 & 7.5 & 29 \\
\hline Fiesta & 41 & 3.5 & 2 & 1.5 & 23 \\
\hline Dumara & 40 & 2.5 & 2 & 4.5 & 26 \\
\hline Crimson Sweet & 41 & 3.5 & 3 & 6.5 & 28 \\
\hline Sentinel & 48 & 10.5 & 3 & 7.5 & 29 \\
\hline Slice N'Serve 830 & 29 & -8.5 & 3 & -5.5 & 16 \\
\hline WX 55 & 38 & 0.5 & 4 & -3.5 & 18 \\
\hline TRI-X-Palomar & 44 & 6.5 & 4 & 2.5 & 24 \\
\hline Celebration & 38 & 0.5 & 4 & -3.5 & 18 \\
\hline Mardi Gras & 35 & -2.5 & 4 & -6.5 & 15 \\
\hline Revolution & 24 & -13.5 & 5 & -8.5 & 13 \\
\hline Til & 45 & 7.5 & 5 & 12.5 & 34 \\
\hline SeedWay 4502 & 30 & -7.5 & 5 & -2.5 & 19 \\
\hline Wrigley & 32 & -5.5 & 5 & -10.5 & 11 \\
\hline HMX 8914 & 22 & -15.5 & 8 & -7.5 & 14 \\
\hline EX 4510759 & 35 & -2.5 & 8 & -10.5 & 11 \\
\hline TRI-X-313 & 28 & -9.5 & 8 & -1.5 & 20 \\
\hline Falcon & 46 & 8.5 & 9 & -0.5 & 21 \\
\hline Millionaire & 20 & -17.5 & 9 & -8.5 & 13 \\
\hline Freedom & 21 & -16.5 & 10 & -6.5 & 15 \\
\hline W 5052 & 19 & -18.5 & 10 & -8.5 & 13 \\
\hline Millenium & 25 & -12.5 & 11 & -1.5 & 20 \\
\hline W 5051 & 16 & -21.5 & 12 & -9.5 & 12 \\
\hline Gem-Dandy & 35 & -2.5 & 12 & 9.5 & 31 \\
\hline Athens & 58 & 20.5 & 13 & 7.5 & 29 \\
\hline Stargazer & 36 & -1.5 & 14 & 12.5 & 34 \\
\hline Regency & 54 & 16.5 & 14 & 2.5 & 24 \\
\hline Premiere & 28 & -9.5 & 16 & 6.5 & 28 \\
\hline WX 8 & 55 & 17.5 & 18 & -0.5 & 21 \\
\hline Pinata LS & 59 & 21.5 & 20 & 1.5 & 23 \\
\hline Starbrite & 51 & 13.5 & 22 & -8.5 & 13 \\
\hline SF var. 800 & 60 & 22.5 & 27 & -4.5 & 17 \\
\hline Mean & 37.5 & - & 9.1 & - & 21.5 \\
\hline
\end{tabular}

${ }^{\mathrm{y}}$ Deviation from the mean = injury for an individual cultigen minus the mean for all cultigens for a given year.

${ }^{\mathrm{z}}$ Difference $=$ absolute value of difference between deviations from the mean in 2000 and 2001.

$1.5 \%$ injury [3] and as high as $45 \%[15])$. Based on the level of variability expected from yearly differences in $\mathrm{O}_{3}$ levels and the inherent variability of certain cultigens, these results are surprisingly similar to our own.

In 1987, Simini et al. (15) reported on the sensitivity of watermelon cultivars under ambient conditions in southwestern Indiana over three consecutive years. They speculated that yield may not be correlated with foliar injury, but provided no data to support this. In 1991, Snyder et al. (16) followed up on this work by testing a single cultivar ('Sugar Baby') in open-top chambers and reported watermelon yield losses of up to $21 \%$ due to ozone injury. Because of space constraints, open-top chamber studies are limited to few plants. Moreover, the chamber produces an environment whose total effect on growth and reproduction is not known. Thus, the effects measured with a single cultivar using few plants under an altered environment may not extrapolate to agricultural production systems (7).

The strength of our study is that we were able to evaluate a large number of cultigens under ambient conditions. This necessarily precluded a reduced- $\mathrm{O}_{3}$ control. Nonetheless, it is reasonable to expect that cultigens with high levels of foliar injury would have lower yields. Although the correlation with yield was not as high as expected $(r=-0.31)$, and was only significant in 2001, we showed a consistent negative correlation between foliar injury and yield (i.e., total harvested weight). A comparison of cultigens grown under ambient conditions in low- $\mathrm{O}_{3}$ watermelon production areas (e.g., Oregon) might be a suitable control for the same cultigens grown under high- $\mathrm{O}_{3}$ environments and provide a more realistic measure of yield reduction by ozone. The timing of injury development may partly explain the lack of high correlation between injury and yield. That is, foliar injury occurred too

Table 3. Summary statistics for five yield and fruit quality characters and their correlation with percent foliar injury induced by $\mathrm{O}_{3}$

\begin{tabular}{|c|c|c|c|c|c|c|c|c|}
\hline \multirow{3}{*}{$\begin{array}{l}\text { Variable } \\
\text { Year }\end{array}$} & \multirow{2}{*}{\multicolumn{4}{|c|}{$\begin{array}{c}\text { Simple statistics } \\
\text { All cultigens }\end{array}$}} & \multicolumn{4}{|c|}{ Correlation with \% injury } \\
\hline & & & & & \multicolumn{2}{|c|}{ All cultigens } & \multicolumn{2}{|c|}{ Common cultigens } \\
\hline & Min & Max & Mean & Std dev. & $r^{\mathbf{z}}$ & $P^{\mathbf{z}}$ & $r$ & $P$ \\
\hline \multicolumn{9}{|c|}{ Days-to-harvest } \\
\hline 2000 & 68 & 83 & 74 & 3 & -0.413 & $<0.0001$ & -0.443 & $<0.0001$ \\
\hline 2001 & 74 & 98 & 86 & 4 & -0.484 & $<0.0001$ & -0.333 & 0.0001 \\
\hline \multicolumn{9}{|c|}{ Total harvested weight $(\mathrm{kg} / \mathrm{ha})$} \\
\hline 2000 & 41 & 162 & 104 & 24 & -0.046 & 0.4604 & -0.062 & 0.4835 \\
\hline 2001 & 100 & 287 & 195 & 37 & -0.310 & $<0.0001$ & -0.274 & 0.0018 \\
\hline \multicolumn{9}{|c|}{ Fruit weight $(\mathrm{kg})$} \\
\hline 2000 & 4.2 & 11.5 & 7.0 & 1.4 & 0.347 & $<0.0001$ & 0.358 & $<0.0001$ \\
\hline 2001 & 3.5 & 12.4 & 7.6 & 1.5 & -0.096 & 0.1385 & -0.088 & 0.3234 \\
\hline \multicolumn{9}{|c|}{ Length/diameter } \\
\hline 2000 & 0.8 & 2.1 & 1.4 & 0.3 & -0.401 & $<0.0001$ & 0.366 & $<0.0001$ \\
\hline 2001 & 1.0 & 2.1 & 1.3 & 0.3 & -0.005 & 0.9362 & 0.036 & 0.6903 \\
\hline \multicolumn{9}{|c|}{ Soluble solids $(\%)$} \\
\hline 2000 & 9.7 & 13.6 & 11.9 & 0.6 & -0.186 & 0.0027 & -0.179 & 0.0428 \\
\hline 2001 & 9.4 & 13.1 & 11.6 & 0.7 & -0.126 & 0.0504 & -0.031 & 0.7242 \\
\hline
\end{tabular}

${ }^{\mathrm{z}} r=$ Pearson correlation coefficient; $P=$ probability. 
late to affect yield, especially in the first harvest. The observation that $\mathrm{O}_{3}$ injury did not develop on newer foliage indicates that there may be a limit to how early injury can occur under field conditions. This is in contrast to Decoteau et al. (3), who stated that injury eventually spread to new growth.

Several other workers have speculated that early-maturing cultivars that produce round fruit with high sugar content are highly sensitive to $\mathrm{O}_{3}$ damage $(15,16)$. These speculations were based on observations with relatively few cultivars. In our study with 93 cultigens, there was a consistently significant negative correlation between early maturation and ozone injury (i.e., the fewer days-to-harvest the greater the sensitivity to $\mathrm{O}_{3}$ ) in 2000 and 2001 , thus confirming previous speculation. This does not mean that ozone injury causes certain cultigens to yield earlier than nor- mal, but rather, that early-yielding cultigens may be more susceptible to ozone injury. Fruit shape (length/diameter) was not consistently correlated to foliar injury, and sugar content (soluble solids) was negatively correlated with foliar injury but only significant in 2000. The fact that 'Sugar Baby' is highly sensitive to $\mathrm{O}_{3}$ and produces small, round fruit, high in soluble solids, might explain why earlier workers made this speculation. However, our data, which are based on a larger number of cultigens, do not support this.

One of the more important findings of this study is that $\mathrm{O}_{3}$ sensitivity is associated with ploidy. This finding provides growers with an important management tool and may provide an important clue to determining how tolerance to $\mathrm{O}_{3}$ is inherited. At least one other researcher has noted that triploid cultivars may possess high levels of tolerance to ozone injury (5),

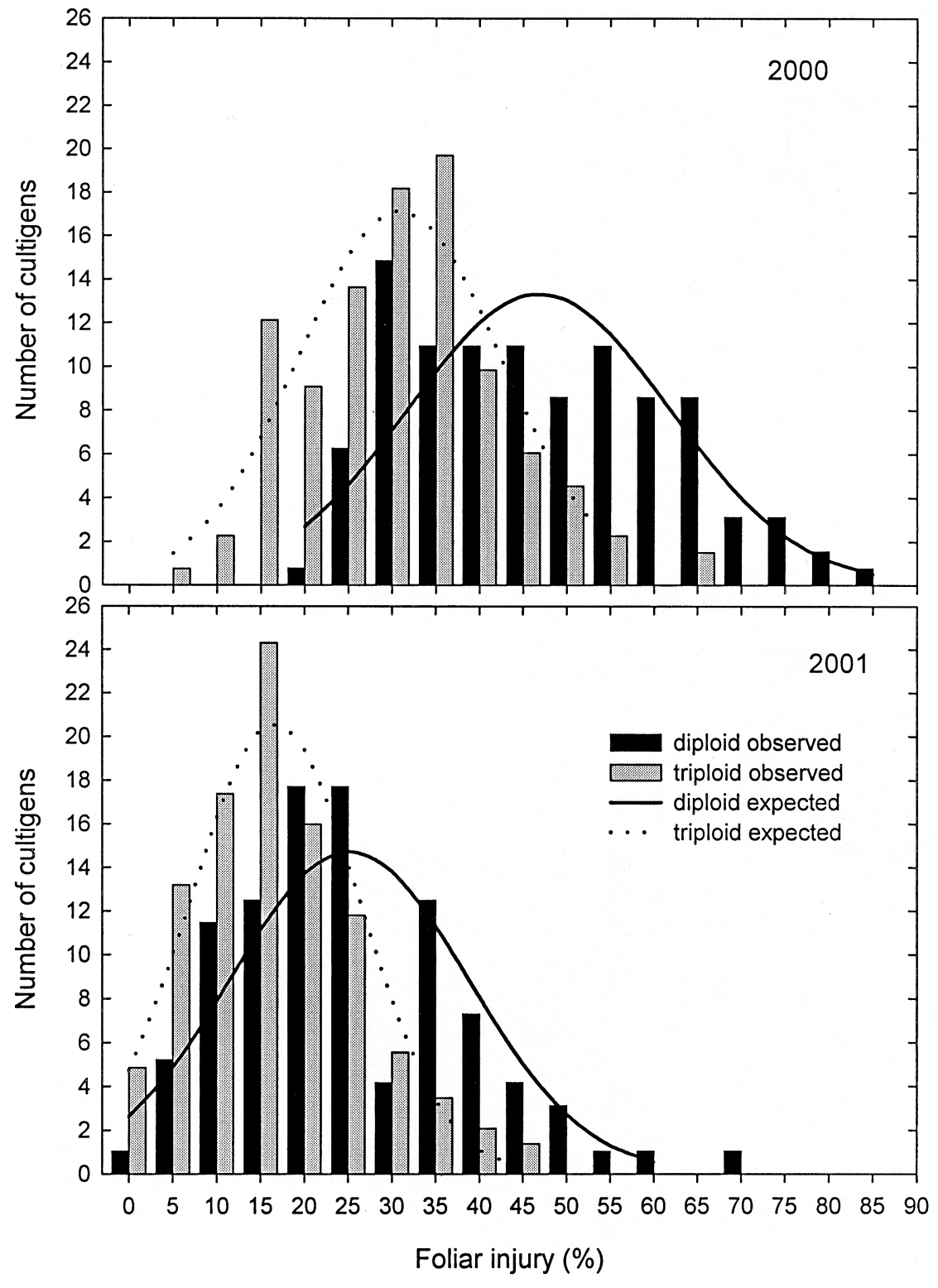

Fig. 3. Frequency distribution of $\mathrm{O}_{3}$ sensitivity in watermelon cultigens. Expected values for a normal distribution are indicated by curved lines. but the current study is apparently the first to demonstrate this.

In watermelon breeding programs, a large number of parental lines are used to produce hybrid cultivars. In contrast, relatively few tetraploid parents are used. The tetraploid we tested was not highly tolerant to $\mathrm{O}_{3}$, but a larger number of tetraploids should be screened before any conclusions are drawn about the source of ozone tolerance in triploid cultivars. Plant breeders should determine the heritability of $\mathrm{O}_{3}$ sensitivity and routinely evaluate their breeding materials in areas where $\mathrm{O}_{3}$ is known to cause severe foliar injury.

\section{ACKNOWLEDGMENTS}

The technical assistance of D. E. Adams and M. J. Adams are gratefully acknowledged. Thanks to A. S. Heagle and R. Reinert of the USDA Air Quality Research Unit in Raleigh, NC, for assistance in diagnosing $\mathrm{O}_{3}$ injury, for $\mathrm{O}_{3}$ measurements, and for their critical review of this manuscript.

\section{LITERATURE CITED}

1. Benton, J., Fuhrer, J., Gimeno, B. S., Skärby, L., and Sanders, G. 1995. Results from the UN/ECE ICP-Crops indicate the extent of exceedance of the critical levels of ozone in Europe. Water, Air Soil Pollution 85:14731478.

2. Carnahan, J. E., Jenner, E. L., and Wat, E. K. W. 1978. Prevention of ozone injury to plants by a new protectant chemical. Phytopathology 68:1225-1229.

3. Decoteau, D. R., Simon, J. E., Eason, G., and Reinert, R. A. 1986. Ozone-induced injury on field-grown watermelons. HortScience 21:1369-1371.

4. Gimeno, B. S., Bermejo, V., Reinert, R. A., Zheng, Y., and Barnes, J. D. 1999. Adverse effects of ambient ozone on watermelon yield and physiology at a rural site in Eastern Spain. New Phytol. 144:245-260.

5. Gimeno, B. S., Peñuelas, J., Porcuna, J. L., and Reinert, R. A. 1995. Biomonitoring ozone phytotoxicity in eastern Spain. Water, Air Soil Pollution 85:1521-1526.

6. Gimeno, B. S., Salleras, J. M., Porcuna, J. L., Reinert, R. A., Velissarious, D., and Davison, A. W. 1995. The use of watermelon as an ozone bioindicator. Pages 55-62 in: Bioindicators of Environmental Health. M. H. Munawar, O. Hänninen, S. Roy, S. Munawar, L. Kärenlampi, and D. Brown, eds. SPB Academic Publishing, Amsterdam, Netherlands.

7. Heagle, A. S. 1989. Ozone and crop yield. Annu. Rev. Phytopathol. 27:397-423.

8. Heagle, A. S., and Stefanski, L. A. 2000. Relationships between ambient ozone regimes and white clover forage production using different ozone exposure indexes. Atmos. Environ. 34:735-744.

9. Holmes, G. J., and Schultheis, J. R. 2001. Susceptibility of watermelon cultigens to ozone injury, 2000. Biol. Cult. Tests 16:V109.

10. Holmes, G. J., Schultheis, J. R., Adams, M. L., and Adams, D. 2002. Susceptibility of watermelon cultigens to ozone injury, 2001. Biol. Cult. Tests 17:V24.

11. Krupa, S., McGrath, M. T., Andersen, C. P., Booker, F. L., Burkey, K. O., Chappelka, A. H., Chevone, B. I., Pell, E. J., and Zilinskas, B. A. 2001. Ambient ozone and plant health. Plant Dis. 85:4-12.

12. Reinert, R., Sanchez, B., Salleras, J. M., Bermejo, V., Ochoa, M. J., and Tarruel, A. 1992. Ozone effects on watermelon plants at 
the Ebro Delta (Spain): Symptomatology. Agric. Ecosyst. Eviron. 38:41-49.

13. Reinert, R. A., Heggestad, H. E., and Heck, W. W. 1982. Response and genetic modification of plants for tolerance to air pollutants. Pages 259-292 in: Breeding Plants for Less Favorable Environments. M. N. Christiansen and C. G. Lewis, eds. John Wiley \& Sons, New York.

14. Sanders, D. C., ed. 2001. Vegetable crop guidelines for the southeastern U.S. North Carolina Coop. Ext. Serv.

15. Simini, M., Snyder, R. G., and Simon, J. E. 1987. Differential sensitivity of muskmelon and watermelon cultivars to ozone-induced foliar injury. Indiana Acad. Sci. 96:121-127.

16. Snyder, R. G., Simon, J. E., Reinert, R. A., Simini, M., and Wilcox, G. E. 1991. Effects of air quality on growth, yield, and quality of watermelon. HortScience 26:1045-1047.
17. Taylor, G. S., and Rich, S. 1974. Ozone injury to tobacco in the field influenced by soil treatments with benomyl and carboxin. Phytopathology 64:814-817.

18. U.S. Environmental Protection Agency. 1996 Air Quality Criteria for Ozone and Related Photochemical Oxidants. EPA/600-90/004bF, National Center for Environmental Assessment, Office of Research and Development, Research Triangle Park, NC. 